\title{
SIMULATION OF ELECTRON DIFFUSION EFFECT ON PLASMA FORMATION IN SILICON TRAPATT DIODES
}

\author{
J. Vyšniauskas ${ }^{\text {a }}$, V. Klimenko ${ }^{\text {b }}$, . Matukas ${ }^{\text {a }}$, and V. Palenskis ${ }^{a}$ \\ ${ }^{a}$ Faculty of Physics, Vilnius University, Sauletekio 9, LT-10222 Vilnius, Lithuania \\ E-mails: juozas.vysniauskas@ff.vu.lt; jonas.matukas@ff.vu.lt; vilius.palenskis@ff.vu.lt \\ ${ }^{\mathrm{b}}$ West Department of Pushkov Institute of Terrestrial Magnetism, Ionosphere and Radio Wave Propagation of the RAS, \\ Pobedy 41, 236017 Kaliningrad, Russia \\ E-mail: vvk_48@mail.ru
}

Received 30 July 2012; revised 5 September 2012; accepted 20 September 2012

\begin{abstract}
Plasma formation and extraction processes in silicon $\mathrm{n}^{+} \mathrm{np}^{+}$TRAPATT (TRApped Plasma Avalanche Triggered Transit) diodes were simulated. The drift-diffusion model was chosen for the simulation of the processes. This model is adequate for diodes under consideration with a total thickness of $6.5 \mu \mathrm{m}$. Two approximations of carrier diffusion coefficient dependence on the electric field above $20 \mathrm{kV} / \mathrm{cm}$ were used. A strong dependence of plasma density and oscillation period on $\mathrm{n}^{+} \mathrm{n}$ junction steepness was found in the case of a constant electron diffusion coefficient in the electric field range above $20 \mathrm{kV} / \mathrm{cm}$. This behaviour depends on the impact ionization model in silicon. Two models were used. In one of them we included drift and diffusion current in the impact ionisation process. In the other model we included only the drift current in the impact ionisation process. In the second case the influence of the $n^{+} n$ junction steepness on the plasma formation process is much stronger. In the diodes with a highly abrupt $n^{+} n$ junction the TRAPATT mode is impossible. These results explain our experiments on TRAPATT diodes with an abrupt $\mathrm{n}^{+} \mathrm{n}$ junction.
\end{abstract}

Keywords: simulation, avalanche diodes, diffusion

PACS: $85.30 . \mathrm{Mn}$

\section{Introduction}

The operation of an avalanche diode in TRAPATT mode is possible exclusively in the case of a large signal. Due to a very large amplitude (compared to direct current) of voltage and current oscillation, a microwave generator with a TRAPATT diode can generate large power with high efficiency [1]. Because of a very strong nonlinearity of the TRAPATT diode, the current and voltage contain high order harmonics of up to 7 or 10. This allows to us generate not only sinusoidal oscillations on the microwave load, but triangular pulses with sub-nanosecond duration as well. This feature of the TRAPATT diode may be utilised in modern radar systems with a non-sinusoidal carrier. Our experiments show that a typical TRAPATT diode with a static breakdown voltage of about $90 \mathrm{~V}$ and a $\mathrm{p}^{+} \mathrm{n}$ junction diameter of $250 \mu \mathrm{m}$ generates triangular pulses with a $100 \mathrm{~V}$ amplitude and a $0.3 \mathrm{~ns}$ duration on a $50 \mathrm{Ohm}$ load [2, 3]. On the load of $5 \mathrm{Ohm}$ the generator provides a current of $6.3 \mathrm{~A}$. This feature is very useful for the direct modulation of a powerful laser diode with a gigabit per second rate.

Despite the fact that TRAPATT diodes were invented many years ago [4], the plasma formation and extraction processes in these diodes are not well understood. In particular, this applies to the carrier diffusion influence on the plasma formation in the high electric field region $(50-200 \mathrm{kV} / \mathrm{cm})$. A relatively high punch-through factor $(F=3-5)$ of TRAPATT diodes leads to a high electric field in $\mathrm{n}^{+} \mathrm{n}$ interface and to a high initial current for the beginning of dynamic avalanche breakdown. As a result, we have lower carrier density in trapped plasma and a more rapid plasma extraction. The value of the initial current depends on the $n^{+} n$ junction steepness [5] and the electron diffusion 
coefficient in that junction. Thus the knowledge of the value of the electron diffusion coefficient in the abovementioned electric field range is very important. However, well-known experiments provide us with data for the electron diffusion coefficient in silicon in the electric field range below $50 \mathrm{kV} / \mathrm{cm}$ [6]. These data show that the electron diffusion coefficient decreases with the increase of the electric field in the range below $20 \mathrm{kV} / \mathrm{cm}$. In the range of the electric field between 20 and $50 \mathrm{kV} / \mathrm{cm}$ the electron diffusion coefficient is almost constant. We assume in our calculations that the electron diffusion coefficient remains constant in the electric field range above $20 \mathrm{kV} / \mathrm{cm}$. Quite often in avalanche diode simulation the authors use another approximation: the electron diffusion coefficient decreases with the increase of the electric field above $20 \mathrm{kV} / \mathrm{cm}$ 沼. Our calculations show that these two approximations give us quite different results in the diodes with an abrupt $\mathrm{n}^{+} \mathrm{n}$ junction.

Another problem is the calculation of the carrier generation term due to impact ionisation. Two approaches are usually used. In one of them the carrier generation term due to impact ionisation includes the total particle current density (drift plus diffusion) [7-10]. In the second approach the carrier generation term includes only the drift current density [1]. We could not find any papers in which computer simulation of TRAPATT diodes uses the second approach. The main purpose of our work is the simulation of plasma formation and extraction processes in a silicon $n^{+} n p^{+}$TRAPATT diode using the second approach for the calculation of the carrier generation term due to impact ionisation and comparison with the results obtained when using the first approach. The differences between the results of these two approaches depend on the $n^{+} n$ junction steepness.

\section{TRAPATT diode model}

The doping distribution in the $n^{+} n p^{+}$TRAPATT diode with various steepness of the $n^{+} n$ junction is shown in Fig. 1. Donor $N_{\mathrm{d}}(x)$ and acceptor $N_{\mathrm{a}}(x)$ distribution is approximated by a well-known function $\operatorname{erfc}(x)$ :

$$
N_{\mathrm{d}}(x)=N_{\mathrm{d}}(x)-N_{\mathrm{a}}(x), \text { when } N_{\mathrm{d}}(x)>N_{\mathrm{a}}(x),
$$

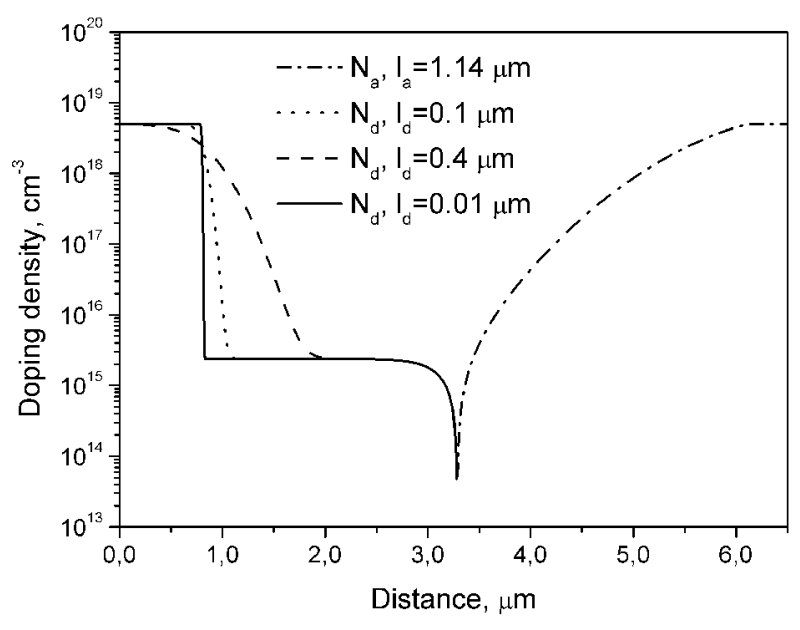

Fig. 1. The doping distribution of the simulated diodes with various steepness of the $n^{+} n$ region.

$$
\begin{aligned}
& N_{\mathrm{d}}(x)=0, \text { when } N_{\mathrm{d}}(x) \leq N_{\mathrm{a}}(x), \\
& N_{\mathrm{d}}(x)=N_{\mathrm{a}}(x)-N_{d}^{\prime}(x) \text {, when } N_{\mathrm{a}}(x)>N_{\mathrm{d}}(x), \\
& N_{\mathrm{a}}(x)=0 \text {, when } N_{\mathrm{a}}^{\prime}(x) \leq N_{\mathrm{d}}^{\prime}(x), \\
& N_{\mathrm{d}}^{\prime}(x)=N_{\mathrm{d} 1}+\left(N_{\mathrm{d} 0} / 2\right) \cdot \operatorname{erfc}\left(\left(x-x_{\mathrm{d}}\right) / l_{\mathrm{d}}\right), \\
& N_{\mathrm{a}}^{\prime}(x)=N_{\mathrm{a} 0} \operatorname{erfc}\left(\left(x_{\mathrm{a}}-x\right) / l_{\mathrm{a}}\right) \text {, when } x \leq x_{\mathrm{a}}, \\
& N_{a}(x)=N_{a 0} \text {, when } x>x_{a} \text { and } x<w
\end{aligned}
$$

where $x$ is distance, $N_{\mathrm{d} 0}=N_{\mathrm{a} 0}=5 \cdot 10^{18} \mathrm{~cm}^{-3}$, $N_{\mathrm{d} 1}=2.4 \cdot 10^{15} \mathrm{~cm}^{-3}, x_{\mathrm{a}}=6.1 \mu \mathrm{m}, l_{\mathrm{a}}=1.14 \mu \mathrm{m}$, $l_{\mathrm{d}}=\left(10^{-2}-0.8\right) \mu \mathrm{m}, w=6.5 \mu \mathrm{m}$.

For computer simulation of the TRAPATT diode we used a one dimension drift-diffusion model based on continuity equations for electrons and holes and Poisson's equation:

$$
\begin{aligned}
& \frac{\partial n}{\partial t}-\frac{\partial J_{n}}{\partial x}=G-R,(2.8) \\
& \frac{\partial p}{\partial t}+\frac{\partial J_{p}}{\partial x}=G-R, \\
& \frac{\partial E}{\partial x}=\frac{q}{\varepsilon \varepsilon_{0}}\left(p-n+N_{\mathrm{d}}(x)-N_{\mathrm{a}}(x)\right),
\end{aligned}
$$

where $t$ is time, $n$ is electron density, $p$ is hole density, $E$ is electric field intensity, $J_{\mathrm{n}}$, $J_{\mathrm{p}}$ is electron and hole current density normalised to electronic charge, $G$ is charge generation term due to impact 
ionisation, $R$ is hole electron generation and recombination term, $q$ is electronic charge, $\varepsilon=12$, $\varepsilon_{0}=8.85 \cdot 10^{-14} \mathrm{~F} / \mathrm{cm}$.

$$
\begin{aligned}
& J_{\mathrm{n}}=n v_{\mathrm{n}}\left(E, N_{\mathrm{d}}, N_{\mathrm{a}}\right)+\frac{\partial}{\partial x}\left(D_{\mathrm{n}}\left(E, N_{\mathrm{d}}, N_{\mathrm{a}}\right) \cdot n\right), \\
& J_{\mathrm{p}}=p v_{\mathrm{p}}\left(E, N_{\mathrm{d}}, N_{\mathrm{a}}\right)-\frac{\partial}{\partial x}\left(D_{\mathrm{p}}\left(E, N_{\mathrm{d}}, N_{\mathrm{a}}\right) \cdot p\right),
\end{aligned}
$$

where $v_{\mathrm{n}}$ is electron drift velocity, $v_{\mathrm{p}}$ is hole drift velocity, $D_{\mathrm{n}}$ is electron diffusion coefficient, $D_{\mathrm{p}}$ is hole diffusion coefficient. For $v_{\mathrm{n}}$ and $v_{\mathrm{p}}$ we used the following expressions:

$$
\begin{aligned}
& v_{\mathrm{n}}\left(E, N_{\mathrm{d}}, N_{\mathrm{a}}\right)= \\
& v_{\mathrm{ns}}\left(1-\exp \left(-\frac{\mu_{0 \mathrm{n}}\left(N_{\mathrm{d}}, N_{\mathrm{a}}\right)|E|}{v_{\mathrm{ns}}}\right)\right) \operatorname{sign}(E), \\
& v_{\mathrm{p}}\left(E, N_{\mathrm{d}}, N_{\mathrm{a}}\right)= \\
& v_{\mathrm{ps}}\left(1-\exp \left(-\frac{\mu_{0 \mathrm{p}}\left(N_{\mathrm{d}}, N_{\mathrm{a}}\right)|E|}{v_{\mathrm{ps}}}\right)\right) \operatorname{sign}(E),
\end{aligned}
$$

where $v_{\mathrm{ns}}$ and $v_{\mathrm{ps}}$ is electron and hole saturation velocity equal to $10^{7} \mathrm{~cm} / \mathrm{s}, \mu_{0 \mathrm{n}}$ and $\mu_{0 \mathrm{p}}$ is low field mobility of electrons and holes [讯:

$$
\begin{aligned}
& \mu_{0 \mathrm{n}} \quad \text { d }, \quad \text { a }= \\
& \frac{\mu_{00 \mathrm{n}}}{\left(1+\left(N_{\mathrm{d}}+N_{\mathrm{a}}\right) /\left(\frac{N_{\mathrm{d}}+N_{\mathrm{a}}}{S_{\mathrm{n}}}+N_{\mathrm{n}}\right)\right)^{1 / 2}}, \\
& \mu_{0 \mathrm{p}}\left(N_{\mathrm{d}}, N_{\mathrm{a}}\right)= \\
& \frac{\mu_{00 \mathrm{p}}}{\left(1+\left(N_{\mathrm{d}}+N_{\mathrm{a}}\right) /\left(\frac{N_{\mathrm{d}}+N_{\mathrm{a}}}{S_{\mathrm{p}}}+N_{\mathrm{p}}\right)\right)^{1 / 2}},
\end{aligned}
$$

where $\mu_{00 \mathrm{n}}=1350 \mathrm{~cm}^{2} /(\mathrm{V} \cdot \mathrm{s}), S_{\mathrm{n}}=350, N_{\mathrm{n}}=$ $3 \cdot 10^{16} \mathrm{~cm}^{-3}, \mu_{00 \mathrm{p}}=480 \mathrm{~cm}^{2} /(\mathrm{V} \cdot \mathrm{s}), S_{\mathrm{p}}=81, N_{\mathrm{p}}=$ $4 \cdot 10^{16} \mathrm{~cm}^{-3}$.

For $D_{\mathrm{n}}$ and $D_{\mathrm{p}}$ we used two approaches. In the first approach we used approximations from [7] for the whole electric field range:

$$
\begin{aligned}
& D_{\mathrm{n}}\left(E, N_{\mathrm{d}}, N_{\mathrm{a}}\right)=\frac{K T \mu_{00 n}}{q} \\
& \times\left[1+\left(N_{\mathrm{d}}+N_{\mathrm{a}}\right) /\left(\frac{N_{\mathrm{d}}+N_{\mathrm{a}}}{S_{\mathrm{n}}}+N_{\mathrm{n}}\right)\right. \\
& \left.+\frac{\left(E / A_{\mathrm{n}}\right)^{2}}{\left(|E| / A_{\mathrm{n}}\right)+F_{\mathrm{n}}}+\left(E / B_{\mathrm{n}}\right)^{2}\right]^{-1 / 2},
\end{aligned}
$$

$$
\begin{aligned}
& D_{\mathrm{p}}\left(E, N_{\mathrm{d}}, N_{\mathrm{a}}\right)=\frac{K T \mu_{00 \mathrm{p}}}{q} \\
& 8\left[1+\left(N_{\mathrm{d}}+N_{a}\right) /\left(\frac{N_{\mathrm{d}}+N_{\mathrm{a}}}{S_{\mathrm{p}}}+N_{\mathrm{p}}\right)\right. \\
& \left.+\frac{\left(E / A_{\mathrm{p}}\right)^{2}}{\left(|E| / A_{\mathrm{p}}\right)+F_{\mathrm{p}}}+\left(E / B_{\mathrm{p}}\right)^{2}\right]^{-1 / 2}
\end{aligned}
$$

where $K$ is Boltzmann constant, $T$ is temperature, $A_{\mathrm{n}}=3.5 \cdot 10^{3} \mathrm{~V} / \mathrm{cm}, F_{\mathrm{n}}=8.8, B_{\mathrm{n}}=7.4 \cdot 10^{3} \mathrm{~V} / \mathrm{cm}$, $A_{\mathrm{p}}=6.1 \cdot 10^{3} \mathrm{~V} / \mathrm{cm}, F_{\mathrm{p}}=1.6, B_{\mathrm{p}}=2.5 \cdot 10^{4} \mathrm{~V} / \mathrm{cm}$.

In the second approach we used Eqs. (2.17) and (2.18) for $D_{\mathrm{n}}$ and $D_{\mathrm{p}}$ in the electric field range below $20 \mathrm{kV} / \mathrm{cm}$. Above $20 \mathrm{kV} / \mathrm{cm}$ we assumed $D_{\mathrm{n}}\left(E, N_{\mathrm{d}}, N_{\mathrm{a}}\right)=D_{\mathrm{n}}\left(20 \mathrm{kV} / \mathrm{cm}, N_{\mathrm{d}}, N_{\mathrm{a}}\right)$ and $D_{\mathrm{p}}\left(E, N_{\mathrm{d}}, N_{\mathrm{a}}\right)=D_{\mathrm{p}}\left(20 \mathrm{kV} / \mathrm{cm}, N_{\mathrm{d}}, N_{\mathrm{a}}\right)$.

For the generation term $G$ we used two approaches as well. In the first approach [7-10]

$$
G=\alpha(E)\left|J_{\mathrm{n}}\right|+\beta(E)\left|J_{\mathrm{p}}\right|,
$$

where $J_{\mathrm{n}}$ and $J_{\mathrm{p}}$ include both drift and diffusion parts of particle current density (Eqs. (2.11) and (2.12)). In the second approach [11]

$$
G=\alpha(E)\left|n v_{\mathrm{n}}\right|+\beta(E)\left|p v_{\mathrm{p}}\right|,
$$

where the diffusion part of particle current density is omitted. Ionisation coefficients for electrons and holes are represented by well-known expressions:

$$
\alpha(E)=a_{\mathrm{n}} \exp \left(-\left(b_{\mathrm{n}} /|E|\right)\right),
$$




$$
\beta(E)=a_{\mathrm{p}} \exp \left(-\left(b_{\mathrm{p}} /|E|\right)\right)
$$

where $a_{\mathrm{n}}=3.8 \cdot 10^{6} \mathrm{~cm}^{-1}, b_{\mathrm{n}}=1.75 \cdot 10^{6} \mathrm{~V} / \mathrm{cm}$, $a_{\mathrm{p}}=2.25 \cdot 10^{7} \mathrm{~cm}^{-1}, b_{\mathrm{p}}=3.26 \cdot 10^{6} \mathrm{~V} / \mathrm{cm}$.

The hole electron generation and recombination through defects are represented by a ShockleyRead-Hall single-level model which characterises defects with neutral and single-charge states. The generation recombination rate through a singlelevel centre is given by

$$
R=\frac{n \cdot p-n_{\mathrm{i}}^{2}}{\tau_{\mathrm{n}}\left(p+p_{\mathrm{t}}\right)+\tau_{\mathrm{p}}\left(n+n_{\mathrm{t}}\right)},
$$

where $n_{\mathrm{i}}$ is intrinsic particle density, $\tau_{\mathrm{n}}=\tau_{\mathrm{p}}=10^{-9} \mathrm{~s}$, $n_{\mathrm{t}}, p_{\mathrm{t}}$ is electron and hole density in the conduction band when the Fermi level coincides with the energy level of the single-level trap, $n_{\mathrm{t}}=p_{\mathrm{t}}=10^{14} \mathrm{~cm}^{-3}$.

At the boundary, it is assumed that the surfacestate density is high enough so that the surface recombination velocity is infinite and the semiconductor is very extrinsic. Hence, the particle density at the boundary is [8]:

$$
\begin{aligned}
& n(0)=N_{\mathrm{d}}(0), \quad p(0)=\frac{n_{\mathrm{i}}^{2}}{N_{\mathrm{d}}(0)}, \\
& p(w)=N_{\mathrm{a}}(w), \quad n(w)=\frac{n_{\mathrm{i}}^{2}}{N_{\mathrm{a}}(w)} .
\end{aligned}
$$

The electric field on the left or the right boundary is calculated by solving the total current equation:

$$
J(t)=\varepsilon \varepsilon_{0} \frac{\partial E}{\partial t}+q J_{\mathrm{n}}+q J_{\mathrm{p}}
$$

All calculations were made assuming a constant total current.

Initial conditions for $n, p$ and $E$ are calculated by solving Poisson's equation in equilibrium:

$$
\begin{aligned}
& \frac{\partial^{2} \phi(x)}{\partial x^{2}}=-\frac{q}{\varepsilon \varepsilon_{0} \varphi_{T}}\left(n_{\mathrm{i}} \exp (-\phi(x))-\right. \\
& \left.n_{\mathrm{i}} \exp (\phi(x))+N_{\mathrm{d}}(x)-N_{\mathrm{a}}(x)\right),
\end{aligned}
$$

where $\phi(x)=\left(\varphi_{F}(x)-\varphi_{F \mathrm{i}}\right) / \varphi_{T}, \varphi_{F}$ is Fermi potential, $\varphi_{F \mathrm{i}}$ is Fermi potential in the intrinsic semicon- ductor, $\varphi_{\mathrm{T}}=K \cdot T / q$. Then the electron and hole density are represented as follows:

$$
\begin{aligned}
& n(x)=n_{\mathrm{i}} \exp (\phi(x)), \\
& p(x)=n_{\mathrm{i}} \exp (-\phi(x)) .
\end{aligned}
$$

The electric field

$$
E(x)=-\varphi_{T} \frac{\partial \phi(x)}{\partial x} .
$$

When solving Eq. (2.27) we need the initial values for $\phi(x)$. These values are calculated from the equation:

$$
\begin{aligned}
& n_{\mathrm{i}} \exp (-\phi(x))-n_{\mathrm{i}} \exp (\phi(x)) \\
& +N_{\mathrm{d}}(x)-N_{\mathrm{a}}(x)=0 .
\end{aligned}
$$

\section{The computer simulation method}

In this numerical method, a well-known timespace mesh [8] is chosen to derive the difference equations. The diode is divided into $i_{\mathrm{w}}$ partitions. If needed, $\Delta x_{i}=x_{j+1}-x_{j}$ varies in space. The electron density, hole density, and doping density are defined at both ends of each partition at points $j$. There are $j_{\mathrm{w}}=i_{\mathrm{w}}+1$ such points. In the middle of two $j$ points, there are $i$ points. The electric field intensity, particle current density, and those material parameters which are functions of the electric field intensity are defined at these $i$ points. For the particle current densities in points $i$ we used slightly modified Gummel and Scharfetter [7] expressions:

$$
J_{\mathrm{n} i}=\frac{v_{\mathrm{n}}\left(E_{i}\right) \cdot\left(n_{j}-n_{j+1} \exp \left(\left(v_{\mathrm{n}}\left(E_{i}\right) / D_{\mathrm{n}}\left(E_{i}\right)\right) \cdot \Delta x_{i}\right)\right)}{1-\exp \left(\left(v_{\mathrm{n}}\left(E_{i}\right) / D_{\mathrm{n}}\left(E_{i}\right)\right) \cdot \Delta x_{i}\right)}
$$

$$
J_{\mathrm{p} i}=\frac{v_{\mathrm{p}}\left(E_{i}\right) \cdot\left(p_{j+1}-p_{j} \exp \left(\left(v_{\mathrm{p}}\left(E_{i}\right) / D_{\mathrm{p}}\left(E_{i}\right)\right) \cdot \Delta x_{i}\right)\right)}{1-\exp \left(\left(v_{\mathrm{p}}\left(E_{i}\right) / D_{\mathrm{p}}\left(E_{i}\right)\right) \cdot \Delta x_{i}\right)}
$$

Continuity equations for electrons and holes derived in difference form according to the timespace mesh were solved using the flow sweep method [12, 13]. For flow variables we used particle 
currents $J_{\mathrm{n} i}$ and $J_{\mathrm{p} i}$. When solving the continuity equation for electrons at the $(k+1)$ th time step we used the hole density and the electric field intensity from the $k$ th time step. After that we used the calculated electron density at the $(k+1)$ th time step to obtain the hole density at the same time step. Finally we used the calculated electron and hole density to obtain the electric field intensity at the $(k+1)$ th time step by solving Poisson's equation. A self-consistent solution for the electron and hole density and the electric field intensity at the $(k+1)$ th time step is obtained after finishing the iteration process. Usually 2-4 iterations are needed.

The nonlinear equation (2.27) was solved by using the Newton iteration method. The difference equations after linearization at each iteration step were solved by a well-known sweep method. Usually 5-7 iterations were needed.

\section{The computer simulation results}

The typical voltage oscillation on the TRAPATT diode (total current density $J=$ const) is shown in Fig. 2. Due to a large punch-through factor of the TRAPATT diode all active (n) region is depleted at a relatively low voltage. In our calculation we used the initial $(t=0)$ diode voltage $18.5 \mathrm{~V}$. At $t=0$ we applied the constant total current density $J=3 \mathrm{kA} / \mathrm{cm}^{2}$. Carrier density in the depletion region is very low, about $10^{3}-10^{4} \mathrm{~cm}^{-3}$. Thus, almost the whole current

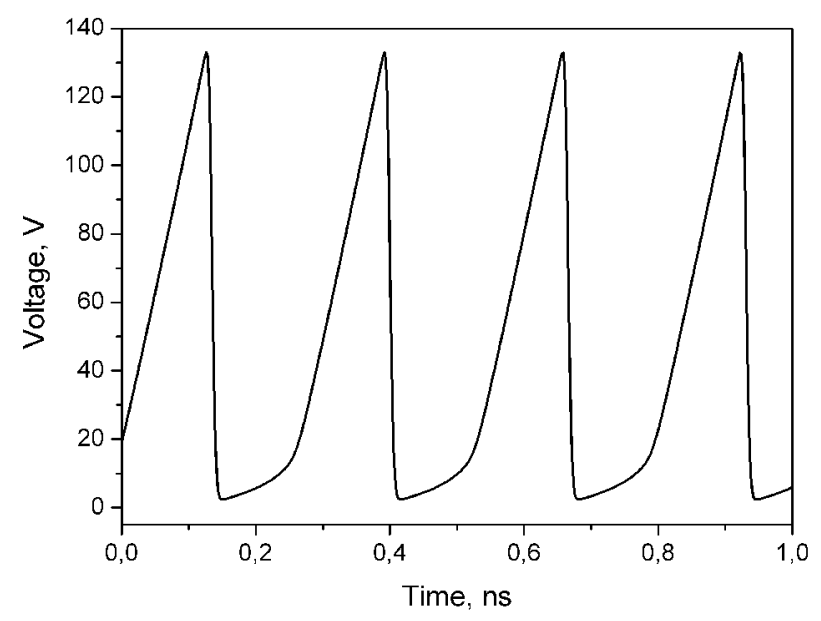

Fig. 2. Voltage oscillation on the TRAPATT diode with $l_{\mathrm{d}}=0.1 \mu \mathrm{m}$, diffusion included in the generation term $G$ and using second approach for $D_{\mathrm{n}}(E)$ and $D_{\mathrm{p}}(E)$. Total current density $J=3 \mathrm{kA} / \mathrm{cm}^{2}$. is the displacement current and we have the electric field increasing at a constant rate. This process is very similar to capacitor charging by the constant current. As we can see in Fig. 2, the diode voltage increases linearly until very intensive impact ionisation begins. The carrier density increases rapidly. Near the voltage maximum point the carrier density becomes much larger than the donor density in the active layer and according to Poisson's equation the carrier density defines the electric field shape. In the centre of the active layer the electric field decreases with time. The diode voltage decreases as well. In the time interval of about several picoseconds the diode voltage decreases to a very low value $(1-2 \mathrm{~V})$. We have a very high carrier density (above $10^{16} \mathrm{~cm}^{-3}$ ) in a low electric field $(600-700 \mathrm{~V} / \mathrm{cm})$. Almost in the whole active region $n-p=N_{\mathrm{d}}$, which indicates electron-hole-ionised donor plasma. The next process is the plasma extraction in the low field. During this process (100-120 ps) the diode voltage increases from $1-2 \mathrm{~V}$ to about $10 \mathrm{~V}$. The carrier density in the active region is very low after plasma extraction. So, almost the whole current is the displacement current. The diode voltage increases again and the next oscillation period begins. The oscillation period depends on plasma extraction time. It depends on carrier density in plasma and the applied total current density. Larger current density leads to a more rapid increase of diode voltage, a higher voltage maximum, and a more intensive impact ionisation process. As a result we have denser electron-hole plasma and a prolonged plasma extraction process. Thus, the oscillation period increases with the total current density increase.

The diode voltage maximum and plasma density depend on the initial particle current density in the beginning of the impact ionisation process. A more intensive initial particle current density leads to diode voltage maximum and plasma density decrease. In silicon the impact ionisation coefficient of electrons $\alpha(E)$ is about ten times greater than the corresponding coefficient of holes $\beta(E)$. Thus, the electrons play the main role at least in the beginning of the impact ionisation process. The generation term for electrons $G=\left.\alpha(E)\right|_{\mathrm{n}} \mid$ (the first approach) or $G=\alpha(E)\left|n v_{\mathrm{n}}\right|$ (the second approach). Our calculations show that the generation term maximum is in the $n^{+} n$ interface because the electron density decreases and the electric field intensity increases with distance (Figs. 3-5). In all these figures we can 

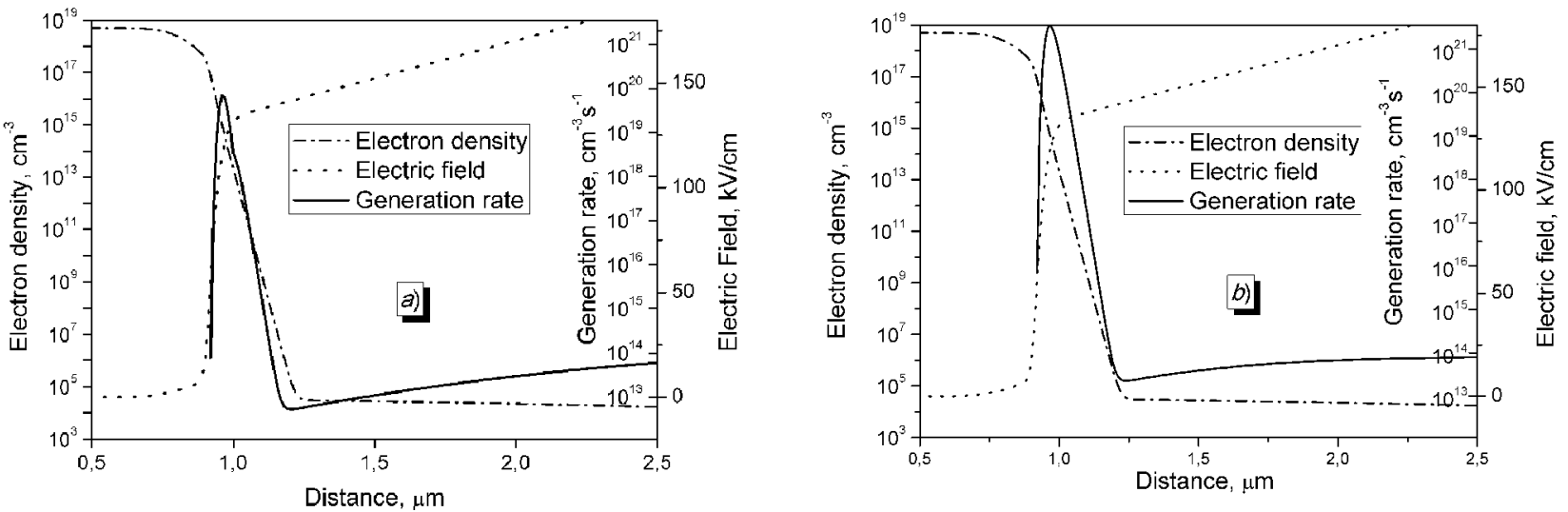

Fig. 3. Electron density, electric field and generation rate in the $\mathrm{n}^{+} \mathrm{n}$ region of the TRAPATT diode with $l_{\mathrm{d}}=0.1 \mu \mathrm{m}$, $t=40$ ps with (a) and without (b) diffusion in the generation term $G$. Second approach for $D_{\mathrm{n}}(E)$ and $D_{\mathrm{p}}(E)$. Total current density $J=3 \mathrm{kA} / \mathrm{cm}^{2}$.
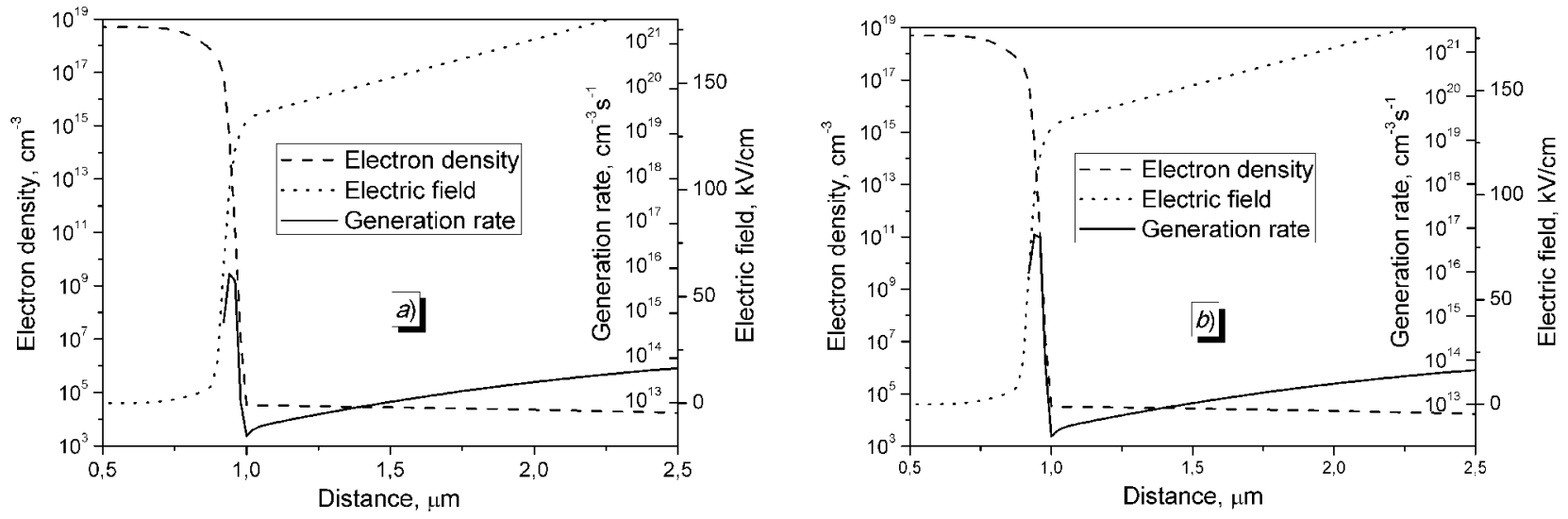

Fig. 4. Electron density, electric field and generation rate in the $\mathrm{n}^{+} \mathrm{n}$ region of the TRAPATT diode with $l_{\mathrm{d}}=0.1 \mu \mathrm{m}$, $t=40 \mathrm{ps}$ with (a) and without (b) diffusion in the generation term $G$. First approach for $D_{\mathrm{n}}(E)$ and $D_{\mathrm{p}}(E)$. Total current density $J=3 \mathrm{kA} / \mathrm{cm}^{2}$.
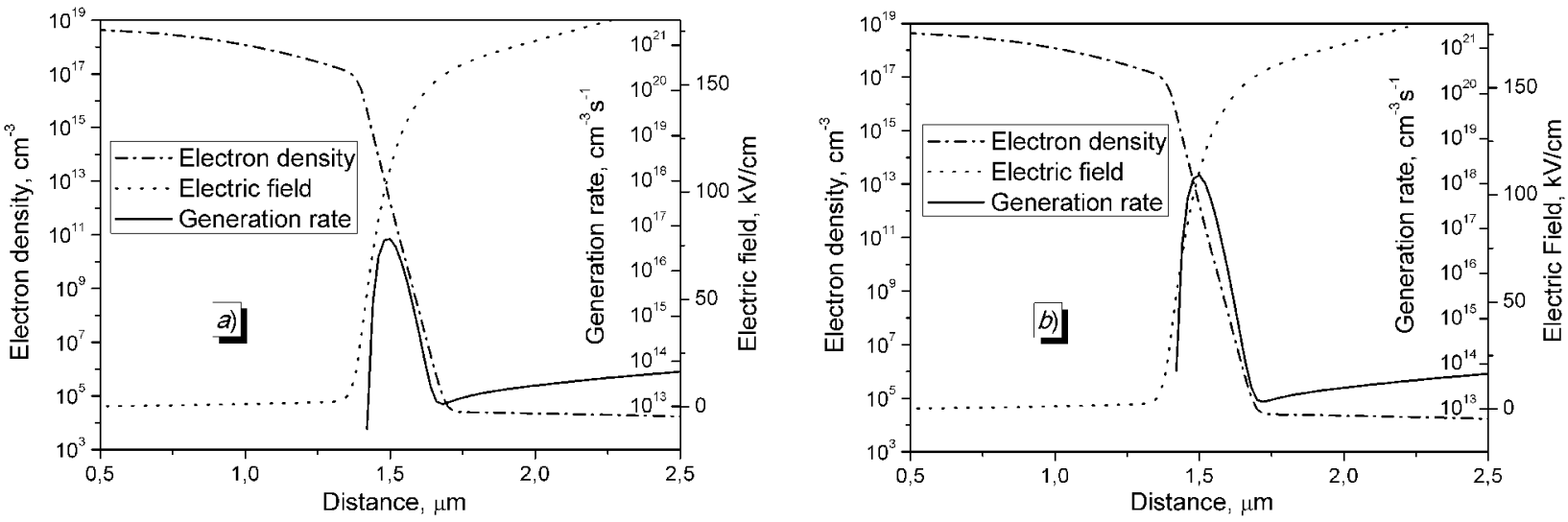

Fig. 5. Electron density, electric field and generation rate in the $\mathrm{n}^{+} \mathrm{n}$ region of the TRAPATT diode with $l_{\mathrm{d}}=0.4 \mu \mathrm{m}$, $t=40 \mathrm{ps}$ with (a) and without (b) diffusion in the generation term $G$. Second approach for $D_{\mathrm{n}}(E)$ and $D_{\mathrm{p}}(E)$. Total current density $J=3 \mathrm{kA} / \mathrm{cm}^{2}$. 
compare the generation rate when using the first approach (Figs. 3a, 4a, 5a) and the second approach (Figs. $3 \mathrm{~b}, 4 \mathrm{~b}, 5 \mathrm{~b}$ ). The generation rate is more than ten times higher in the case of the second approach. It can be explained as follows: the electron drift current flows in the positive $x$ direction and the electron diffusion current flows in the opposite direction $(\partial n / \partial x<0)$, so the total electron current is less than the electron drift current, which we use for the generation rate in the second approach. The initial electron current density and the corresponding generation rate depends on the parameter $l_{\mathrm{d}}$, which describes the $n^{+} n$ junction steepness. A higher $l_{d}$ corresponds to a less abrupt $\mathrm{n}^{+} \mathrm{n}$ junction (Fig. 1). The $\mathrm{n}^{+} \mathrm{n}$ junction steepness parameter $l_{\mathrm{d}}=0.1 \mu \mathrm{m}$ in Fig. 3 and $l_{\mathrm{d}}=0.4 \mu \mathrm{m}$ in Fig. 5. The generation rate in Fig. 3 is more than three orders of magnitude greater than in Fig. 5. It can be explained as follows: in Fig. 5 we have a relatively large $l_{\mathrm{d}}$ and a shallow $\mathrm{n}^{+} \mathrm{n}$ junction. This leads to shallow electric field distribution and relatively low electric field intensity at the maximum of the generation rate. This maximum depends on $\alpha(E)$ which strongly decreases with the electric field intensity decrease.

The generation rate depends on the electron diffusion coefficient $D_{\mathrm{n}}$ in the high electric field region $(50-200 \mathrm{kV} / \mathrm{cm})$. The first approach for $D_{\mathrm{n}}$ leads to a very low $D_{n}$ in the electric field range mentioned above. Thus, we have almost abrupt electron density distribution in the $n^{+} n$ junction (Fig. 4). As a result, electron density at the point of the generation rate maximum is relatively low and the corre- sponding initial current density is low as well. The generation rate in Fig. 5 is more than four orders of magnitude lower than in Fig. 3. We assume that the first approach for carrier diffusion coefficient is not correct.

Carrier density distribution in the TRAPATT diode at various moments of time $(t=10 ; 30 ; 80 \mathrm{ps})$ is shown in Figs. 6 and 7. Figures $6 \mathrm{a}$ and $7 \mathrm{a}$ correspond to the first approach for the generation rate and Figs. $6 \mathrm{~b}$ and $7 \mathrm{~b}$ correspond to the second approach for the generation rate. According to the results discussed earlier the most intensive charge generation is localised in the $n^{+} n$ interface. Hole density increases with time. The main part of holes move to the right, the hole density in the active layer increases. Another part of holes move to the $\mathrm{n}^{+}$ region due to diffusion. The accumulation of holes in the $\mathrm{n}^{+}$region changes the initial current for the next period of voltage oscillation. It will be shown later that such change of the initial current leads to the aperiodic oscillation of the diode voltage in some cases. The hole density in Fig. 6(a, b) differs dramatically, by about three orders of magnitude. This difference in the diode with a shallow $n^{+} n$ junction (Fig. 7) is of only two orders of magnitude. In the diode with a shallow $\mathrm{n}^{+} \mathrm{n}$ junction the electric field shape is shallow as well. The electric field intensity in the $n^{+} n$ interface is low, the generation rate is low and the corresponding hole density is about five orders of magnitude lower than in the diode with an abrupt $n^{+} n$ junction (Fig. 6).

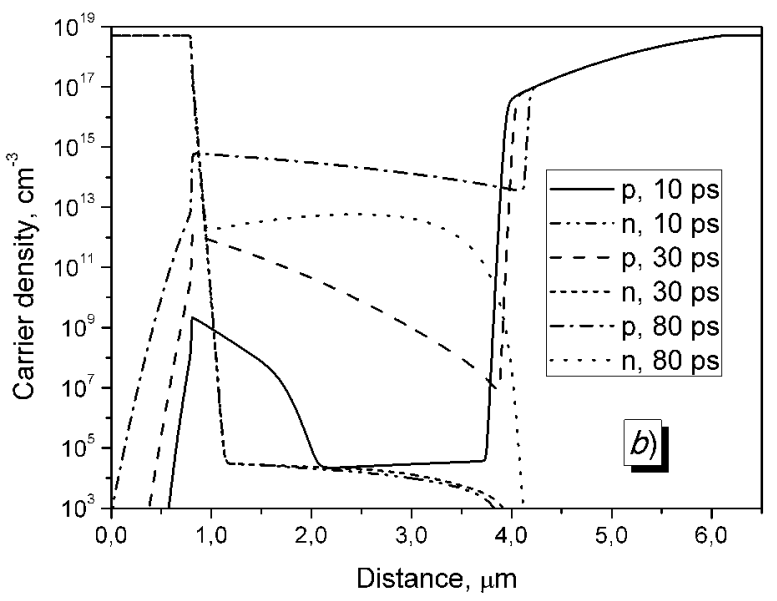

Fig. 6. Carrier density distribution in the TRAPATT diode with $l_{\mathrm{d}}=10^{-2} \mu \mathrm{m}$ and $t=10 ; 30 ; 80$ ps with (a) and without (b) diffusion in the generation term $G$. Second approach for $D_{\mathrm{n}}(E)$ and $D_{\mathrm{p}}(E)$. Total current density $J=3 \mathrm{kA} / \mathrm{cm}^{2}$. 

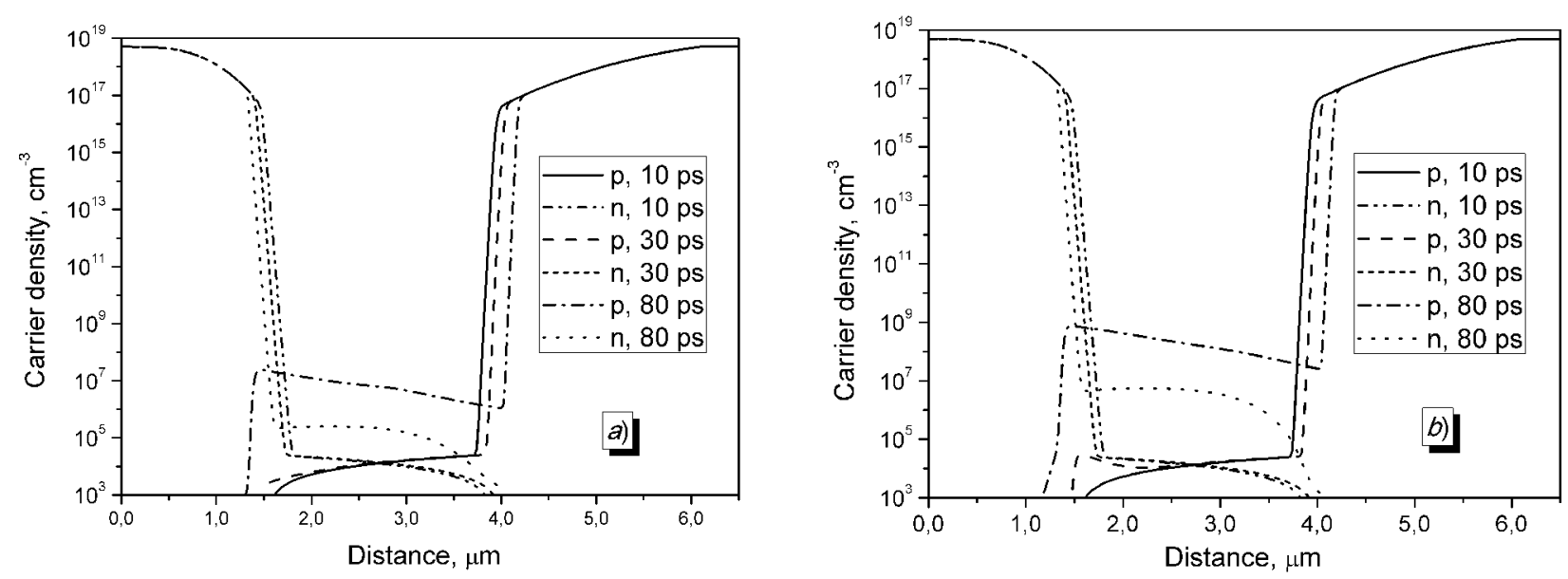

Fig. 7. Carrier density distribution in the TRAPATT diode with $l_{\mathrm{d}}=0.4 \mu \mathrm{m}$ and $t=10 ; 30 ; 80 \mathrm{ps}$ with (a) and without (b) diffusion in the generation term $G$. Second approach for $D_{\mathrm{n}}(E)$ and $D_{\mathrm{p}}(E)$. Total current density $J=3 \mathrm{kA} / \mathrm{cm}^{2}$.

According to the foregoing analysis the shape of the diode voltage oscillation depends on the $\mathrm{n}^{+} \mathrm{n}$ junction steepness, the approach for the generation rate, and the electron diffusion coefficient (Figs. 8-12). The most different results between the two approaches for the generation rate is in the diode with the abrupt $\mathrm{n}^{+} \mathrm{n}$ junction $\left(l_{\mathrm{d}}=10^{-2} \mu \mathrm{m}\right.$, Fig. 8a) when using the second approach for the electron diffusion coefficient. Including diffusion in the generation rate leads to the classical voltage oscillation with plasma formation and extraction processes. The second approach for the generation rate leads to the relaxation oscillation with a low amplitude and a frequency that is more than two times higher. We have no plasma formation in the diode. So, in this case the TRAPATT mode is impossible. Our experiments on TRAPATT diodes show that structures with $l_{\mathrm{d}}$ less than $0.1 \mu \mathrm{m}$ cannot operate in TRAPATT mode. This experimental fact allows us to assume that the second approach for the generation rate is more correct than the first one. Figure $8 \mathrm{~b}$ ) indicates that plasma formation in the diode with an abrupt $n^{+} n$ junction is possible only in case of the first approach for the generation rate. In case of the second approach we have relaxation oscillation with a relatively large amplitude. Increasing $l_{\mathrm{d}}$ to the value of $5 \cdot 10^{-2} \mu \mathrm{m}$ (Fig. 9a) shows similar results to
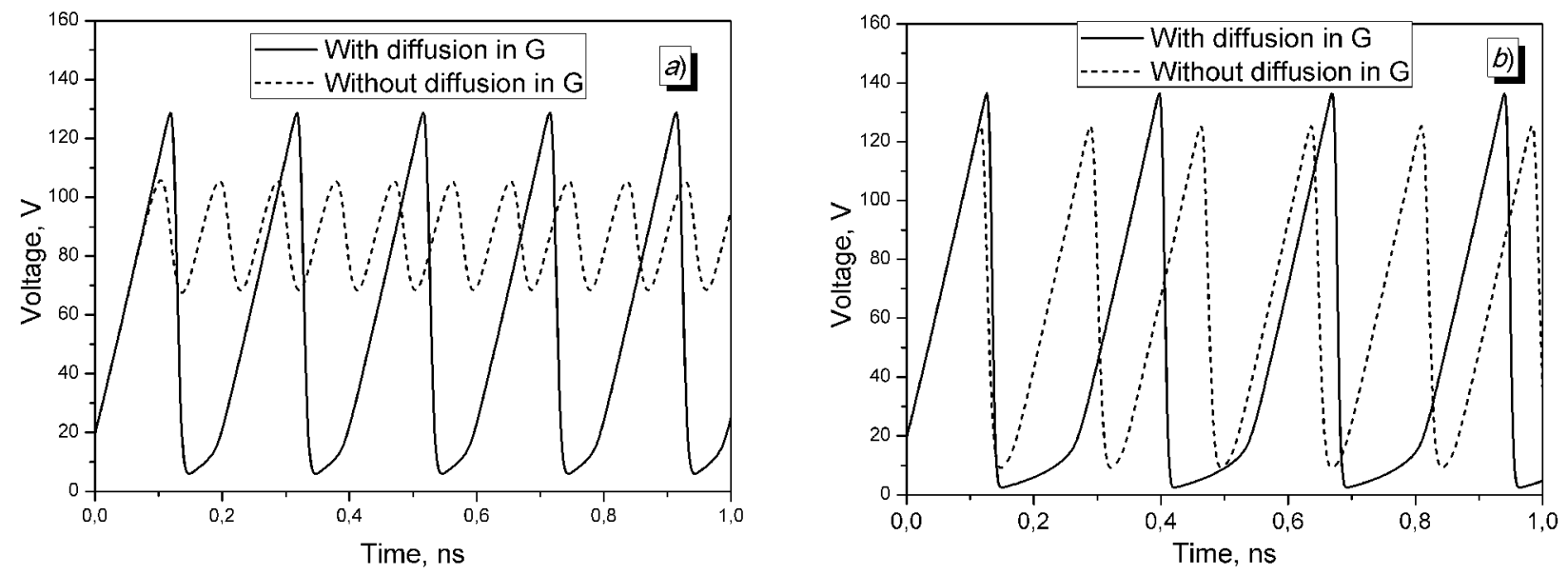

Fig. 8. Voltage oscillation on the TRAPATT diode with $l_{\mathrm{d}}=10^{-2} \mu \mathrm{m}$ with and without diffusion in the generation term $G$ : (a) second and (b) first approach for $D_{\mathrm{n}}(E)$ and $D_{\mathrm{p}}(E)$. Total current density $J=3 \mathrm{kA} / \mathrm{cm}^{2}$. 

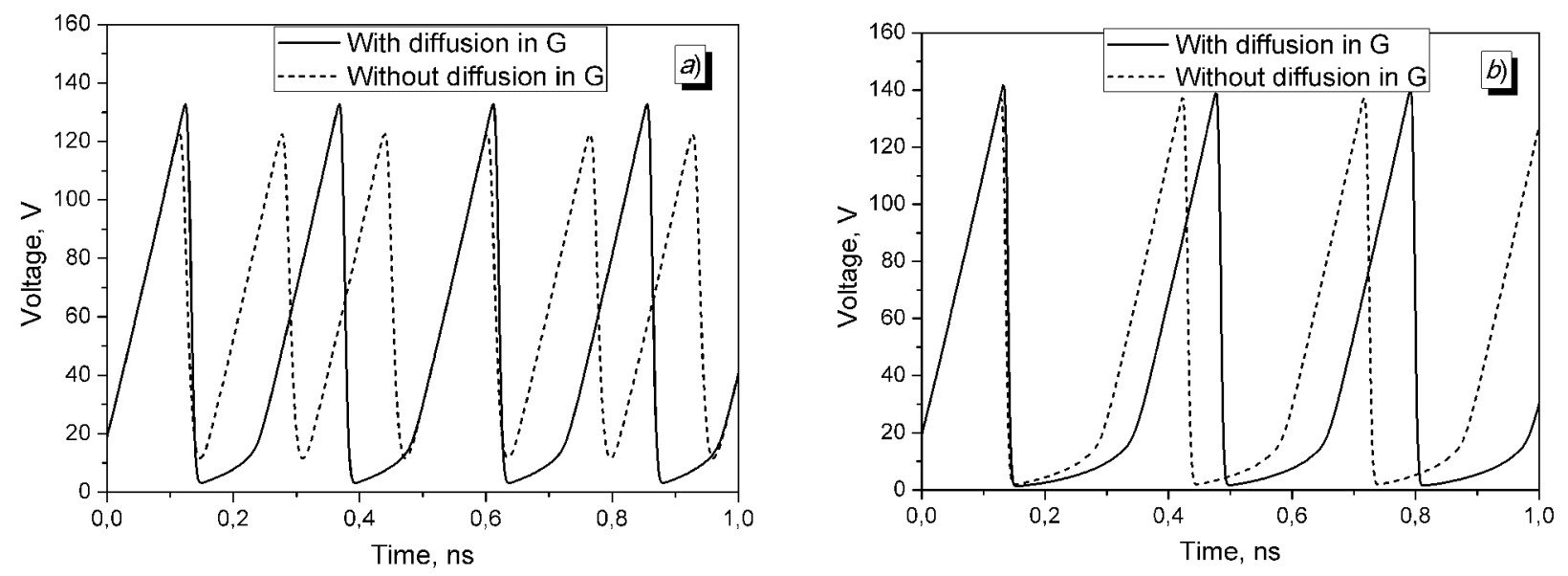

Fig. 9. Voltage oscillation on the TRAPATT diode with $l_{\mathrm{d}}=5 \cdot 10^{-2} \mu \mathrm{m}$ with and without diffusion in the generation term $G$ : (a) second and (b) first approach for $D_{\mathrm{n}}(E)$ and $D_{\mathrm{p}}(E)$. Total current density $J=3 \mathrm{kA} / \mathrm{cm}^{2}$.

that in Fig. 8(a). However, in case of the first approach for $D_{\mathrm{n}}$ and $D_{\mathrm{p}}$ (Fig. $9 \mathrm{~b}$ ) plasma formation in the diode is possible even in case of the second approach for the generation rate. This is contrary to the experimental data. As a result we conclude that the first approach for $D_{\mathrm{n}}$ and $D_{\mathrm{p}}$ is not correct.

Quit periodic oscillation of the diode voltage is shown in Fig. 10. Periodic oscillation indicates that the initial current is the same at the beginning of each oscillation period. Thus, the accumulation of holes in the $\mathrm{n}^{+}$region is very small. Excluding diffusion in the generation rate leads to a higher initial

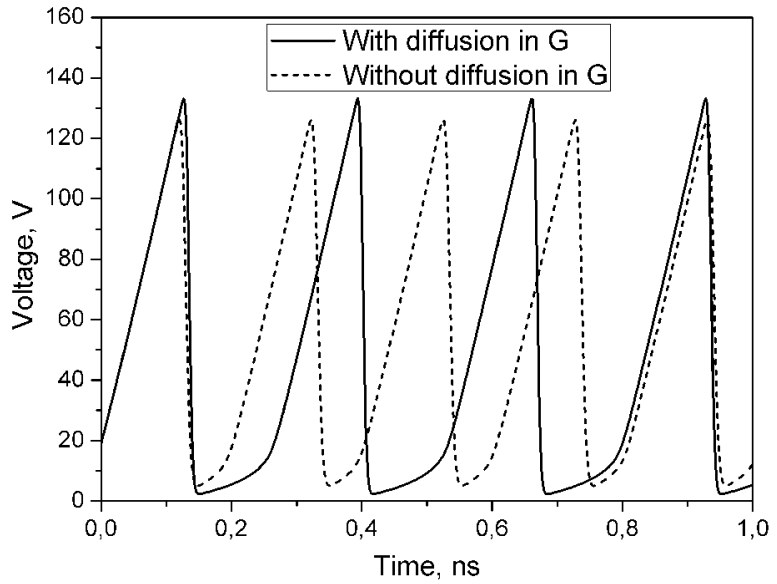

Fig. 10. Voltage oscillation on the TRAPATT diode with $l_{\mathrm{d}}=0.1 \mu \mathrm{m}$ with and without diffusion in the generation term $G$. Second approach for $D_{\mathrm{n}}(E)$ and $D_{\mathrm{p}}(E)$. Total current density $J=3 \mathrm{kA} / \mathrm{cm}^{2}$. current, lower diode voltage maximum, and lower electron-hole plasma density. As a result we have a more rapid plasma extraction and a higher oscillation frequency.

Differences between the two approaches for the generation rate decrease with $l_{\mathrm{d}}$ increase. The diode voltage oscillation in case of $l_{\mathrm{d}}=0.4 \mu \mathrm{m}$ is shown in Fig. 11. The duration of the first period for both approaches differs only by 20 per cent. The diode voltage oscillation is slightly aperiodic due to the hole accumulation in the $\mathrm{n}^{+}$region. The most intensive hole diffusion to the $\mathrm{n}^{+}$region occurs during the plasma extraction period. Afterwards the

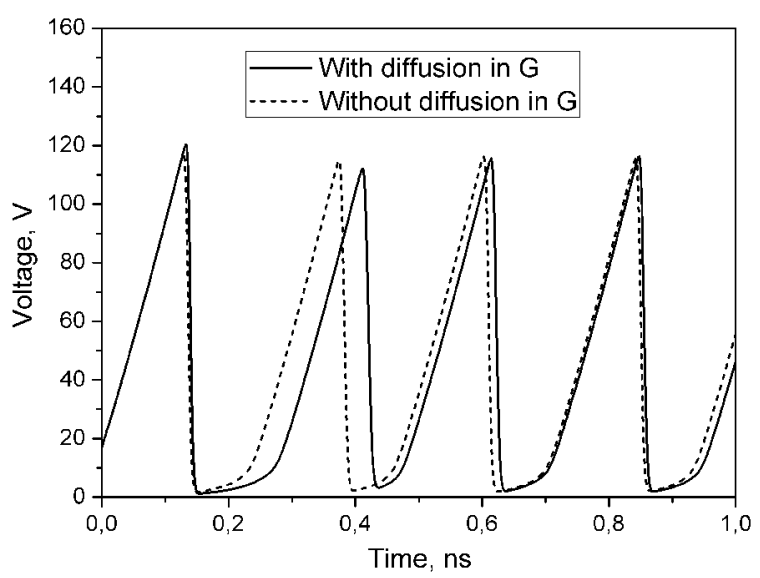

Fig. 11. Voltage oscillation on the TRAPATT diode with $l_{\mathrm{d}}=0.4 \mu \mathrm{m}$ with and without diffusion in the generation term $G$. Second approach for $D_{\mathrm{n}}(E)$ and $D_{\mathrm{p}}(E)$. Total current density $J=3 \mathrm{kA} / \mathrm{cm}^{2}$. 


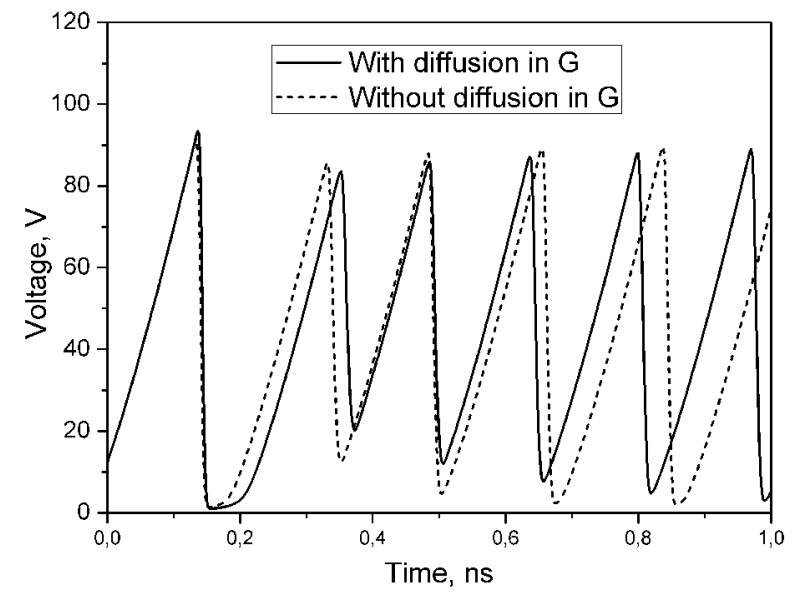

Fig. 12. Voltage oscillation on the TRAPATT diode with $l_{\mathrm{d}}=0.8 \mu \mathrm{m}$ with and without diffusion in the generation term $G$. Second approach for $D_{\mathrm{n}}(E)$ and $D_{\mathrm{p}}(E)$. Total current density $J=3 \mathrm{kA} / \mathrm{cm}^{2}$.

plasma extraction holes return to the active layer by diffusion process. The initial current for the next oscillation period increases due to extra hole density in the depleted active layer. This process plays the most important role in the diode with a shallow $\mathrm{n}^{+} \mathrm{n}$ junction. In Fig. 12 we have the diode voltage oscillation in case of $l_{\mathrm{d}}=0.8 \mu \mathrm{m}$. The diode voltage oscillation is extremely aperiodic. The plasma formation occurs only in the first period of oscillation. The duration of the plasma extraction period is small because of the thin active layer in the diode with a shallow $n^{+} n$ junction.

\section{Conclusions}

Plasma formation and extraction processes in silicon $\mathrm{n}^{+} \mathrm{np}^{+}$TRAPATT diodes were simulated. Two approaches for the carrier diffusion coefficient in the electric field range above $20 \mathrm{kV} / \mathrm{cm}$ were used. The first approach leads to a very low carrier diffusion coefficient and almost abrupt carrier density distribution in the high electric field region. When using this approach the plasma formation process is possible in the diodes with an abrupt $\mathrm{n}^{+} \mathrm{n}$ junction $\left(l_{\mathrm{d}}<0.1 \mu \mathrm{m}\right)$ which is contrary to the experimental data. We assume that the second approach in which the carrier diffusion coefficient is constant in the electric field range above $20 \mathrm{kV} / \mathrm{cm}$ is more correct than the first one. Two approaches were used for the calculation of the charge generation rate due to impact ionisation as well. The most different results for these two approaches are for the diodes with an abrupt $\mathrm{n}^{+} \mathrm{n}$ junction. The first approach includes both drift and diffusion current density in the generation rate and allows the TRAPATT mode even in the diode with $l_{\mathrm{d}}=10^{-2} \mu \mathrm{m}$. Experimental data show that the TRAPATT mode in such diodes is impossible. The second approach includes only drift current density in the generation rate and coincides with experimental data. Thus, we assume that the second approach for the generation rate is more correct.

\section{References}

[1] D.L. Scharfetter, Power-frequency characteristics of the TRAPATT diode mode of high efficiency power generation in germanium and silicon avalanche diodes, Bell Syst. Tech. J. 49(5), 799-826 (1970).

[2] F.K. Vaitiekūnas, J.B. Vyšniauskas, Š.A. Kamaldinov, M.J. Filatov, and G.E. Šimènas, Investigation of the pulse generator external circuit with TRAPATT diode, Tekhnika Sredstv Svyazi. Ser. Radioizmeritel'naya Tekhnika 35(1), 11-16 (1981) [in Russian].

[3] J. Vyšniauskas, Charge Generation and Transport in TRAPATT Structures during the Generation of Nonsinusoidal Oscillation. Doctoral Thesis (Vilnius University, Vilnius, 1985).

[4] H.J. Prager, K.K.N. Chang, and S. Weisbrod, Highpower, high-efficiency silicon avalanche diodes at ultra-high frequencies, Proc. of IEEE 55(4), 586587 (1967).

[5] F.K. Vaitiekūnas, J.B. Vyšniauskas, and M.V. Meilūnas, Influence of $\mathrm{N}^{+} \mathrm{N}$ region steepness to plasma formation and extraction processes in silicon TRAPATT diodes, Elektronnaya Tekhnika, Ser. Elektronika SVCh 361(1), 34-37 (1984) [in Russian].

[6] A. Dargys and J. Kundrotas, Handbook on Physical Properties of Ge, Si, GaAs and InP (Science and Encyclopaedia Publishers, Vilnius, 1994).

[7] D.L. Scharfetter and H.K. Gummel, Large-signal analysis of silicon read diode oscillator, IEEE Trans. Electron Dev. 16(1), 64-77 (1969).

[8] C.M. Lee, R.J. Lomax, and G.I. Haddad, Semiconductor device simulation, IEEE Trans. Microw. Theor. Tech. 22(3), 160-177 (1974).

[9] F. Vaitiekunas and J. Vyshniauskas, Differences of plasma formation and extraction in $\mathrm{P}^{+} \mathrm{NN}^{+}$and $\mathrm{N}^{+} \mathrm{PP}^{+}$silicon TRAPATT structures, Electron. Lett. 17(21), 822-824 (1981).

[10] G. Šimènas and J. Vyšniauskas, Movement of avalanche multiplication intensity maximum during the generation of self-pulsations in $p^{+} n n^{+}$diodes, Lith. J. Phys. 38(1), 25-28 (1998). 
[11] S.A. Mayorov, A.M. Mel'nikov, and A.A. Rudenko, Modelling of semiconductor microstructures with account of impact ionization in strong electric fields, Matematicheskoe Modelirovanie 1(5), 2332 (1989) [in Russian].

[12] L.M. Degtyarev and A.P. Favorskii, Flow variant of sweep method, Zhurnal Vychislitel'noi Matematiki i Matematicheskoi Fiziki (Comput. Math. Math. Phys., in Russian) 8(3), 679-684 (1968).

[13] L.M. Degtyarev and A.P. Favorskii, Flow variant of sweep method for difference tasks with strongly varying coefficients, Zhurnal Vychislitel'noi Matematiki i Matematicheskoi Fiziki (Comput. Math. Math.Phys.,in Russian) 9(1), 211-218 (1969).

\title{
ELEKTRONŲ DIFUZIJOS İTAKOS PLAZMOS SUSIDARYMUI SILICIO TRAPATT DIODUOSE MODELIAVIMAS
}

\author{
J. Vyšniauskas ${ }^{\text {a }}$, V. Klimenko ${ }^{\text {b }}$ J. Matukas ${ }^{\text {a }}$, V. Palenskis ${ }^{a}$ \\ ${ }^{a}$ Vilniaus universiteto Fizikos fakultetas, Vilnius, Lietuva \\ ${ }^{\mathrm{b}}$ Rusijos mokslu akademijos Puškovo Žemès magnetizmo, jonosferos ir radijo bangu sklidimo instituto Vakaru skyrius, \\ Kaliningradas, Rusija
}

\section{Santrauka}

Darbe pateikti plazmos susidarymo ir išsiurbimo procesu $\mathrm{n}^{+} \mathrm{np}^{+}$silicio TRAPATT (TRApped Plasma Avalanche Triggered Transit) dioduose kompiuterinio modeliavimo rezultatai. Procesų modeliavimui buvo pasirinktas dreifinis-difuzinis modelis. Šis modelis tinka minètų diodų modeliavimui, kadangi jų ilgis yra $6,5 \mu \mathrm{m}$. Buvo naudojamos dvi krūvininkų difuzijos koeficiento priklausomybès nuo elektrinio lauko daugiau kaip $20 \mathrm{kV} / \mathrm{cm}$ aproksimacijos. Buvo aptikta stipri plazmos tankio ir virpesių periodo priklausomybe nuo $\mathrm{n}^{+} \mathrm{n}$ sandūros statumo, kai elektronų difuzijos koeficientas yra pastovus elektriniuose laukuose (per $20 \mathrm{kV} / \mathrm{cm}$ ). Šis reiškinys priklauso nuo smūginès jonizacijos modelio silicyje. Buvo naudojami du modeliai. Viename iš jų buvo įvertinta dreifo ir difuzijos srove skaičiuojant krūvio generacijos spartą. Kitame modelyje - įvertinta tik krūvininkų dreifo srovè smūginès jonizacijos procese. Antruoju atveju sandūros statumo įtaka plazmos formavimosi procesui yra daug didesne. Dioduose su ypač stačia $\mathrm{n}^{+} \mathrm{n}$ sandūra TRAPATT moda negalima. Šie rezultatai paaiškina mūsų eksperimentus su stačios $n^{+} n$ sandūros TRAPATT diodais. 